J Arid Land (2015) 7(1): 101-109

doi: $10.1007 / \mathrm{s} 40333-014-0035-3$

jal.xjegi.com; www.springer.com/40333

\title{
Responses of microbial activities and soil physical-chemical properties to the successional process of biological soil crusts in the Gurbantunggut Desert, Xinjiang
}

\author{
BingChang ZHANG, XiaoBing ZHOU, YuanMing ZHANG* \\ Key Laboratory of Biogeography and Bioresources in Arid Land, Xinjiang Institute of Ecology and Geography, Chinese Academy of \\ Sciences, Urumqi 830011, China
}

\begin{abstract}
Biological soil crusts (BSCs) are capable of modifying nutrient availability to favor the establishment of biogeochemical cycles. Microbial activities serve as critical roles for both carbon and nutrient transformation in BSCs. However, little is known about microbial activities and physical-chemical properties of BSCs in the Gurbantunggut Desert, Xinjiang, China. In the present research, a sampling line with 1-m wide and 20-m long was set up in each of five typical interdune areas selected randomly in the Gurbantunggut Desert. Within each sampling line, samples of bare sand sheet, algal crusts, lichen crusts and moss crusts were randomly collected at the depth of $0-2 \mathrm{~cm}$. Variations of microalgal biomass, microbial biomass, enzyme activities and soil physical-chemical properties in different succession of BSCs were analyzed. The relationships between microalgal biomass, microbial biomass, enzymatic activities and soil physical-chemical properties were explored by stepwise regression. Our results indicate that microalgal biomass, microbial biomass and most of enzyme activities increased as the BSCs developed and their highest values occurred in lichen or moss crusts. Except for total $\mathrm{K}$, the contents of most soil nutrients (organic $\mathrm{C}$, total $\mathrm{N}$, total $\mathrm{P}$, available $\mathrm{N}$, available $\mathrm{P}$ and available $\mathrm{K}$ ) were the lowest in the bare sand sheet and significantly increased with the BSCs development, reaching their highest values in moss crusts. However, $\mathrm{pH}$ values significantly decreased as the BSCs developed. Significant and positive correlations were observed between chlorophyll a and microbial biomass C. Total $\mathrm{P}$ and $\mathrm{N}$ were positively associated with chlorophyll $a$ and microbial biomass $\mathrm{C}$, whereas there was a significant and negative correlation between microbial biomass and available $\mathrm{P}$. The growth of cyanobacteria and microorganism contributed $\mathrm{C}$ and $\mathrm{N}$ in the soil, which offered substrates for enzyme activities thus increasing enzyme activities. Probably, improvement in enzyme activities increased soil fertility and promoted the growth of cyanobacteria, eukaryotic algae and heterotrophic microorganism, with the accelerating succession of BSCs. The present research found that microalgal-microbial biomass and enzyme activities played important roles on the contents of nutrients in the successional stages of BSCs and helped us to understand developmental mechanism in the succession of BSCs.
\end{abstract}

Keywords: chlorophyll a; microbial biomass C; soil enzyme; physical-chemical properties; biological soil crusts

Citation: BingChang ZHANG, XiaoBing ZHOU, YuanMing ZHANG. 2015. Responses of microbial activities and soil physical-chemical properties to the successional process of biological soil crusts in the Gurbantunggut Desert, Xinjiang. Journal of Arid Land, 7(1): 101-109. doi: $10.1007 /$ s40333-014-0035-3

Biological soil crusts (BSCs), consisting of eukaryotic algae, cyanobacteria, lichens, fungi, bacteria and mosses that live on the soil surface, are common in harsh habitats where water and nutrients are limited and vascular plant cover is discontinuous (Hawkes and
Flechtner, 2002; Belnap and Lange, 2003). They play a key role in many semi-arid and arid ecosystem functions around the world, by enhancing soil fertility andstability (Belnap and Lange, 2003), preventing water or wind erosion (Belnap and Gillette, 1997), and increas-

*Corresponding author: YuanMing ZHANG (E-mail: zhangym@ms.xjb.ac.cn)

Received 2013-12-09; revised 2014-03-28; accepted 2014-04-17

(C) Xinjiang Institute of Ecology and Geography, Chinese Academy of Sciences, Science Press and Springer-Verlag Berlin Heidelberg 2015 
ing the possibility of vascular plant colonization on sand dunes (Eldridge and Greene, 1994; Belnap and Phillips, 2002).

BSCs can be distinguished into the following successional stages: bare sand sheet, algal crusts, lichen crusts and moss crusts depending on the composition of the dominant organisms (Eldridge and Greene, 1994; Belnap and Lange, 2003; Zhang, 2005; Lan et al., 2012a). Bare sand sheet are largely composed of the uncompacted sand grains. Few filamentous cyanobateria can be found. $\mathrm{C}$ and $\mathrm{N}$ contents in the soil are the lowest (Zhang et al., 2009). Algal crusts show an organic layer formed by filamentous cyanobacteria associated with sand particles. Algal crusts have greater cover of Microcoleus and lower cover of Nostoc compared to the later successional crusts (Zhang, 2005; Housman et al., 2006; Zhang et al., 2009). Once the soil surface has been stabilized by the algal filaments, lichens and mosses appear. Lichen crusts are dominated by Collema tenax, Psora decipiens and Xanthoria elegans, etc. It can be divided into a thallus layer, rhizoid layer and sub-rhizoid layer (Zhang et al., 2010; Lan et al., 2012a). Filamentous cyanobacteria, mainly distributed in the upper lichen crust layer, with fungal mycelium can bind sand grains and thus can thicken crusts. $\mathrm{C}$ and $\mathrm{N}$ fixation rates in lichen crusts are greater than other successional crusts (Belnap, 2002; Evans and Lange, 2003). The final stage in the succession of BSCs is the establishment of moss crusts. The most common moss species are Syntrichia caninervis and Bryum argenteum (Zhang et al., 2010). Moss rhizoids and filamentous cyanobacteria bound to sand particles. With the succession of BSCs, total phototrophic biomass, exopolysaccharides and fine particles accumulated, all of which lead to a gradual increase in crusts thickness (Lan et al., 2012a).

Researchers have found that diversity, species composition of cyanobacteria and biomass showed significant differences in the successional processes of BSCs (Redfield et al., 2002; Zhang et al., 2009; Lan et al., 2012b). Well-developed BSCs significantly increase the organic matter content, microbial activity and biomass ( $\mathrm{Yu}$ et al., 2012). Later successional crusts have greater photosynthesis, nitrogenase activity and chlorophyll fluorescence than those in early successional crusts (Housman et al., 2006; Lan et al., 2012b; Yu et al., 2012). However, some research found that net carbon fluxes have no difference among different crusted soils (Su et al., 2013). Nitrogen-fixing activity is the highest in algal crusts, followed by lichen crusts and moss crusts in Gurbantunggut Desert (Wu et al., 2009). Some other studies conducted the effect of temperatures, dew, soil water contents and litter on carbon exchange and chlorophyll fluorescence in single or several types of BSCs (Harel et al., 2004; Rao et al., 2009; Grote et al., 2010; Su et al., 2013; Zeng et al., 2013). BSCs development affects physical-chemical characteristics of soil surface and microbial activities in arid ecosystems (Guo et al., 2008; Chamizo et al., 2012a; Miralles et al., 2012). Soil microbial activity plays essential roles in soil nutrient transformation (Chen et al., 2006; Glaciela et al., 2010). But the changes of microbial activities with development of BSCs and the relationship between microbial activities and physical-chemical properties in the succession of BSCs remain unknown. Up to now, few studies have analyzed the relationship among microalgal biomass, microbial biomass, enzyme activities and physical-chemical properties in different succession of BSCs. We hypothesize that microbial activity and nutrient content will increase as the BSCs developed. The increase of microbial biomass will lead to positive responses of soil enzyme activities, thus soil nutrients change correspondingly. Our aim is to clarify the mechanism of BSCs succession on the microbial and nutrient levels. Moreover, the relationships between microbial biomass, enzyme activities and physical-chemical properties are determined.

\section{Materials and methods}

\subsection{Study area}

The Gurbantunggut Desert $\left(44^{\circ} 11^{\prime}-46^{\circ} 20^{\prime} \mathrm{N}, 84^{\circ} 31^{\prime}-\right.$ $90^{\circ} 00^{\prime} \mathrm{E}$ ) is the largest fixed and semi-fixed desert in China with an area of $488,000 \mathrm{~km}^{2}$. Mean annual precipitation is approximately $79.5 \mathrm{~mm}$, falling predominantly during spring while mean annual evaporation is $2,606.6 \mathrm{~mm}$. The annual average temperature is $7.26^{\circ} \mathrm{C}$, while the maximum temperature is over $40^{\circ} \mathrm{C}$. Wind speeds are greatest during the late spring, blowing predominantly from the WNW, NW and N direc- 
tions at an average of $11.17 \mathrm{~m} / \mathrm{s}$. With the coverage of less than $30 \%$, natural vegetation is dominated by Haloxylon ammodendron and $H$. persicum. Due to a long steady snow period in winter and increased precipitation in spring, ephemeral and ephemeriod plants are developed. This study was conducted in southern part of the Gurbantunggut Desert due to that abundant BSCs were developed on the sand surface (Zhang et al., 2007; Zhang et al., 2009). The interdune areas are mainly covered by lichen and moss dominated crusts, and the slopes are mainly characterized by algae and lichen dominated crusts (Zhang et al., 2007). Microbial communities in BSCs are dominated by filamentous cyanobacteria, especially Microcoleus vaginatus. Other common species include Cyanothece aeruginosa, Synechococcus parvu, Oscillatoria tenuis, Chlorococcum humicola, Navicula sp. and Hantzschia amphioxys (Zhang et al., 2011).

In April 2011, five typical sand dunes, separated by at least $100 \mathrm{~m}$, were randomly selected in the study area. A sampling line with $1-\mathrm{m}$ wide and 20-m long was set up in each interdune area ( $\mathrm{Su}$ et al. 2011). Within each sampling line, samples of bare dune sands, algal crusts, lichen crusts and moss crusts were randomly collected at the depth of $0-2 \mathrm{~cm}$. For decreasing spatial heterogeneity, five soil samples along one sampling line were collected and mixed together to form one composite sample for each type of BSCs. In total, twenty soil samples were collected for the four types of BSCs. Soil samples were stored in sterilize plastic bags and packed in ice blocks, and then transported to the laboratory. Each sample was divided into two sub-samples: one was stored at $4{ }^{\circ} \mathrm{C}$ and used to analyze chlorophyll $a$, microbial biomass and enzyme activities (Ajwa et al., 1999), and the other was air dried and used to determine soil physical-chemical properties (Zhang et al., 2009; Zhou et al., 2012).

\subsection{Microbial and microalgal biomass}

Chloroform was used to fumigate, extract and estimate microbial biomass $\mathrm{C}$ as described by Vance et al. (1987) and Zhou et al. (2012). Microalgal biomass was determined by chlorophyll $a$ concentration (Zhang et al., 2013). Samples collected for chlorophyll $a$ analysis were immediately extracted with $90 \%$ acetone and dimethyl sulfoxide (DMSO) (Catford et al.,
2007).

\subsection{Soil enzyme activities}

Invertase activity was assayed by incubating $5 \mathrm{~g}$ of soil for $24 \mathrm{~h}$ at $37^{\circ} \mathrm{C}$ in $15 \mathrm{~mL}$ of $8 \%$ sucrose, $5 \mathrm{~mL}$ of phosphate buffer at $\mathrm{pH} 5.5$ and $0.1 \mathrm{~mL}$ of toluene. After filtration, $1 \mathrm{~mL}$ filtrate was added to a $50 \mathrm{~mL}$ flask and heated with 3-mL of 3,5-dinitrosalicylic acid (DNS) at $100^{\circ} \mathrm{C}$ for $5 \mathrm{~min}$. The color was then measured at $508 \mathrm{~nm}$ using a spectrophotometer (Lamda35, USA). Results were expressed as $\mathrm{mg} /(\mathrm{g}$ soil.h) glucose released (Kandeler et al., 2006).

Urease activity was determined by incubating 0.3-0.4 g of moist soil with $1.5 \mathrm{~mL} 79.9 \mathrm{mM}$ urea for $2 \mathrm{~h}$ at $37^{\circ} \mathrm{C}$. Released ammonium was extracted with $13.5 \mathrm{~mL}$ of $2 \mathrm{M} \mathrm{KCl}$ solution and colorimetrically determined according to Kandeler et al. (2006).

Alkaline phosphatase (ALP) was assayed using a modified disodium phenylphosphate method. Briefly, $0.3-0.4 \mathrm{~g}$ of the soil was incubated in $2.0 \mathrm{~mL}$ of $0.2 \mathrm{M}$ borate buffer $(\mathrm{pH} 10.0)$ and $1.0 \mathrm{~mL}$ of $0.2 \mathrm{M}$ buffered phenylphosphate solution at $37^{\circ} \mathrm{C}$ for $3 \mathrm{~h}$. We estimated the released phenol basing on color reaction (Kandeler et al., 2006).

Polyphenol oxidase (PPO) and peroxidase activity were measured spectrophotometrically using pyrogallol (PG) as a substrate (Allison and Jastrow, 2006). Soil sample (1-g dry weight equivalent) was incubated with $10 \mathrm{~mL}$ of $1 \%$ PG substrate for $2 \mathrm{~h}$ at $30^{\circ} \mathrm{C}$ and constantly mixed. For peroxidase assays, $2 \mathrm{~mL}$ of $0.3 \% \mathrm{H}_{2} \mathrm{O}_{2}$ were added to each soil sample and blank. PPO and peroxidase activities were quantified using a spectrophotometer by measuring the absorbance at $430 \mathrm{~nm}$ (Zhou et al., 2012).

\subsection{Soil physical-chemical analysis}

Air-dried soil samples were used to measure organic $\mathrm{C}$, total and available $\mathrm{N}, \mathrm{P}$ and $\mathrm{K}, \mathrm{pH}$, and electrical conductivity. The soil organic $\mathrm{C}$ content was measured by the $\mathrm{K}_{2} \mathrm{Cr}_{2} \mathrm{O}_{7}$ method (Walkley-Blach); total $\mathrm{N}$ by the $\mathrm{CuSO}_{4}$-Se powder diffusion method; total $\mathrm{P}$ by the $\mathrm{HClO}_{4}-\mathrm{H}_{2} \mathrm{SO}_{4}$ digest-colorimetry, total $\mathrm{K}$ by the $\mathrm{NaOH}$ melting-flaming luminosity method; available $\mathrm{P}$ using the Bray-P method; available $\mathrm{N}$ by diffusion; and available $\mathrm{K}$ using $\mathrm{NH}_{4}$-acetate (Chen et al., 2007). The $\mathrm{pH}$ value was measured using a PHS-2C digital acidimeter. Soil conductance was measured using a 
DDS-307 conductometer in a 1:5 ratio of soil and water aqueous extract, and total salt was determined by the weight of salt in $20 \mathrm{~mL} \mathrm{1:5} \mathrm{soil-water} \mathrm{aqueous}$ extract after drying (Chen et al., 2007).

\subsection{Statistical analysis}

All data of soils were expressed in air-dried weight. To improve normality, the data for available $\mathrm{N}$ were converted into square root form. A normal distribution of the data was tested using the Kolmogorov-Smirnov- goodness-of-fit test. The variation of microbial biomass, soil enzyme activities and soil chemical properties in different successional processes of BSCs were evaluated by ANOVA. If the effects were significant, post-hoc analysis was used to test significant differences between pairs of means. Relationships among microbial biomass, enzyme activities and soil physical-chemical properties were determined using stepwise regression analyses.

\section{Results}

\subsection{Microbial biomass}

Significant differences in microbial biomass $\mathrm{C}$ and Chlorophyll $a$ were observed in different successional stages of BSCs $(P<0.01)$. Microbial biomass $\mathrm{C}$ and Chlorophyll $a$ in bare sand sheet were the lowest, increased as BSCs developed, and reached the highest value in lichen crusts, then decreased in moss crusts (Fig. 1).

\subsection{Soil enzyme activity}

Invertase, APP and peroxidase activities showed the similar trends with that of microbial biomass. These enzyme activities were the lowest in bare sand sheet and followed by algal crusts, reaching the highest value in lichen crusts. Urease activity was the lowest in bare sand sheet, and increased significantly with the development of BSCs $(P<0.01)$, reaching the highest value in moss crusts. However, PPO activities showed no significant differences in different successional stages (Fig. 2).

\subsection{Soil physical-chemical properties}

There were significant differences $(P<0.01)$ in contents of organic matter, total $\mathrm{N}$, total $\mathrm{P}$, available $\mathrm{N}$, available $\mathrm{P}$, available $\mathrm{K}, \mathrm{pH}$, conductivity and total salts among the soils sampled from different successional stages of BSCs. However, no significant differences were observed for total $\mathrm{K}$ and $\mathrm{C} / \mathrm{N}$ ratios. The contents of most soil nutrients with the exception of total $\mathrm{K}$ were the lowest in the bare sand sheet and increased significantly as the BSCs developed. They reached the highest values in moss crusts (Table 1). However, $\mathrm{pH}$ values decreased significantly as the BSCs developed.

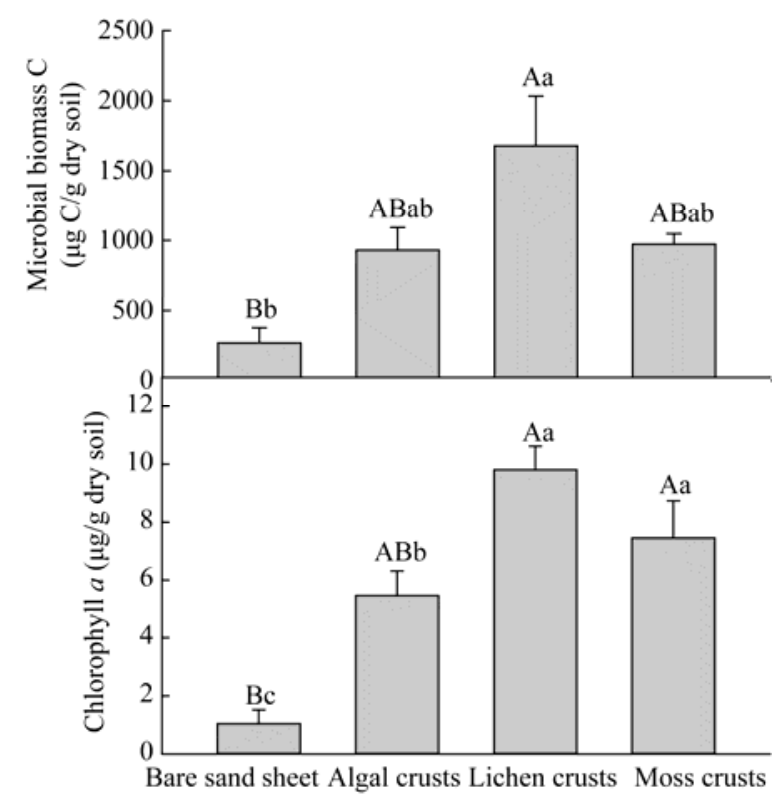

Fig. 1 Microbial biomass $C$ and chlorophyll $a$ in successional stages of BSCs. The different lowercase and uppercase letters indicate significant difference at $P<0.05$ and $P<0.01$ levels, respectively.

\subsection{Relationships between soil nutrients and micr- obial activities}

The relationships among microbial biomass, enzyme activities and soil physical-chemical properties were analyzed by stepwise regression. The results indicated that chlorophyll $a$ was positively related to microbial biomass $(P<0.01)$. APP activity was positively correlated with chlorophyll $a(P<0.01)$ while negatively correlated with microbial biomass $C(P<0.05)$. Urease activity was the main factor influencing organic $C$, total $\mathrm{N}$, available $\mathrm{N}$ and available $\mathrm{K}$, and the correlation between them was significant at $P<0.01$. The content of total $\mathrm{K}$ was not correlated with chlorophyll a, microbial biomass $\mathrm{C}$, and soil enzyme activities. Except that, chlorophyll a and microbial biomass have significant correlation with the contents of total $\mathrm{P}$ and available $\mathrm{P}$, respectively (Table 2 ). 


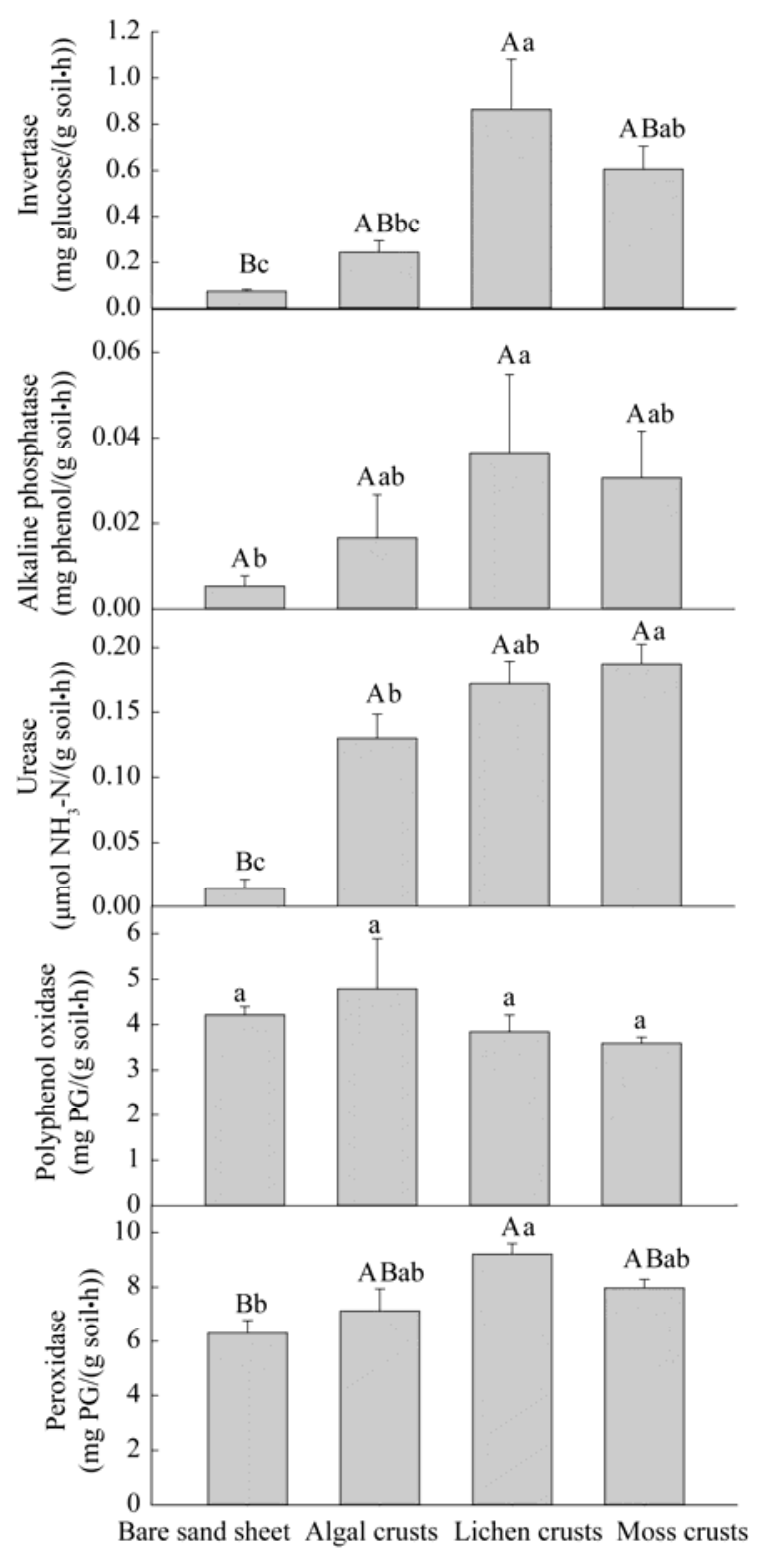

Fig. 2 Enzyme activities in successional stages of BSCs. The different lowercase and uppercase letters indicate significant difference at $P<0.05$ and $P<0.01$ levels, respectively.

\section{Discussion}

\subsection{Changes in microbial activities and physi- cal-chemical properties with the development of BSCs}

In the present study, most microbial activities and nutrient content indices increased with the development of BSCs, which was consistent with our initial hypothesis. Many previous studies had similar results. Chlorophyll $a$, organic-matter content and microbial biomass $\mathrm{C}$ significantly increased in well developed
BSCs, whereas significant differences in functional diversity were not observed between BSCs at different developmental levels (Yu et al., 2012). For the hydrolytic enzymes involved in carbon, nitrogen and phosphorus cycles, hydrolytic activities were higher in BSCs than in the bare sand sheet, and developed in parallel to that of ecological succession (Chamizo et al., 2012b). Meanwhile, the establishment and development of BSCs enhanced the nutrients of the top soil from semi-mobile dune to fixed dune (Guo et al., 2008, Chamizo et al., 2012b). The results in this study highlight the significant role of BSCs for soil fertility in semiarid and arid areas. BSCs protection is necessary for the plants during germination and growth.

\subsection{The role of $\mathbf{C}$ and $\mathbf{N}$ fixation on microbial ac- tivities and soil nutrients in the succession of BSCs}

Arid and semi-arid soils are inherently low in nutrients, especially C, N and P (Housman et al., 2006; Mager and Thomas, 2011). BSCs, as an indicator of rangeland or soil health, play vital role in nutrient cycling and contribute to nutrient pool (Eldridge and Greene, 1994). BSCs consisting of cyanobacteria, eukaryotic algae, lichens and mosses contributed organic $\mathrm{C}$ and $\mathrm{N}$ by photosynthesis and $\mathrm{N}$-fixation directly to the soil ecosystem (Evans and Johansen, 1999; Belnap and Lange, 2003).

The results suggested that chlorophyll $a$ was positively correlated with microbial biomass, total salts and APP. In bare sand sheet, seldom cyanobacteria and eukaryotic algae were found and chlorophyll $a$ was the lowest, thus accumulating a negligible amount of carbon and nitrogen. Due to intimate relationship increase in organic matter and extracellular polysaccharides (Zhang, 2005; Hernandez and Hobbie, 2010; Mager and Thomas, 2011), increasing organic matter and polysaccharides offers a plentiful carbon source for microorganisms and invertase, resulting in an increase of microbial biomass C (Katsalirou et al., 2010; Zhou et al., 2012). Moreover, organic carbon has significant relationship with phosphatases accumulation, and culture studies showed that algal and bacterial cells were likely to have extracellular phosphatase release (Rose and Axler, 1998). Competition for carbon sources between microbial biomass and 
Table 1 Soil physical-chemical properties in different successional stages of BSCs

\begin{tabular}{|c|c|c|c|c|}
\hline Soil physical-chemical property & Bare sand sheet & Algal crusts & Lichen crusts & Moss crusts \\
\hline Organic C (g/kg) & $1.89 \pm 0.21^{\mathrm{Cc}}$ & $3.87 \pm 0.24^{\mathrm{Bb}}$ & $4.98 \pm 0.41^{\mathrm{Bb}}$ & $8.85 \pm 0.33^{\mathrm{Aa}}$ \\
\hline Total N (g/kg) & $0.25 \pm 0.01^{\mathrm{Cc}}$ & $0.57 \pm 0.05^{\mathrm{Bb}}$ & $0.66 \pm 0.08^{\mathrm{Bb}}$ & $1.03 \pm 0.82^{\mathrm{Aa}}$ \\
\hline Total P $(\mathrm{g} / \mathrm{kg})$ & $0.37 \pm 0.01^{\mathrm{Bb}}$ & $0.40 \pm 0.02^{\mathrm{Bb}}$ & $0.48 \pm 0.01^{\mathrm{Aa}}$ & $0.49 \pm 0.01^{\mathrm{Aa}}$ \\
\hline Total K (g/kg) & $14.62 \pm 0.17^{\mathrm{a}}$ & $15.10 \pm 0.97^{\mathrm{a}}$ & $14.61 \pm 0.15^{\mathrm{a}}$ & $14.96 \pm 0.75^{\mathrm{a}}$ \\
\hline Available N (mg/kg) & $16.38 \pm 1.29^{\mathrm{Cc}}$ & $25.88 \pm 2.85^{\mathrm{BCbc}}$ & $47.94 \pm 10.21^{\mathrm{Bb}}$ & $78.95 \pm 3.53^{\mathrm{Aa}}$ \\
\hline Available P (mg/kg) & $2.95 \pm 0.30^{\mathrm{Bb}}$ & $3.54 \pm 0.25^{\mathrm{Bb}}$ & $3.53 \pm 0.41^{\mathrm{Bb}}$ & $6.25 \pm 0.43^{\mathrm{Aa}}$ \\
\hline Available K (mg/kg) & $116.74 \pm 12.67^{\mathrm{Bc}}$ & $143.20 \pm 5.17^{\mathrm{Bbc}}$ & $171.56 \pm 11.15^{\mathrm{Bb}}$ & $242.76 \pm 19.07^{\mathrm{Aa}}$ \\
\hline $\mathrm{C} / \mathrm{N}$ ratio & $7.65 \pm 1.80^{\mathrm{a}}$ & $6.89 \pm 1.16^{\mathrm{a}}$ & $7.76 \pm 1.37^{\mathrm{a}}$ & $8.73 \pm 1.36^{\mathrm{a}}$ \\
\hline $\mathrm{pH}$ & $7.66 \pm 0.19^{\mathrm{Aa}}$ & $7.13 \pm 0.09^{\mathrm{ABb}}$ & $6.84 \pm 0.11^{\mathrm{Bb}}$ & $6.73 \pm 0.11^{\mathrm{Bb}}$ \\
\hline Conductivity $(\mathrm{ms} / \mathrm{cm})$ & $47.82 \pm 2.17^{\mathrm{Bb}}$ & $43.04 \pm 7.96^{\mathrm{Bb}}$ & $73.14 \pm 8.07^{\mathrm{ABab}}$ & $105.06 \pm 10.78^{\mathrm{Aa}}$ \\
\hline Total salt (g/kg) & $0.31 \pm 0.02^{\mathrm{Ab}}$ & $0.34 \pm 0.03^{\mathrm{Ab}}$ & $0.39 \pm 0.04^{\mathrm{Aab}}$ & $0.51 \pm 0.06^{\mathrm{Aa}}$ \\
\hline
\end{tabular}

Note: The different lowercase and uppercase letters indicate significant difference at $P<0.05$ and $P<0.01$ levels, respectively.

Table 2 Relationship between microbial biomass, enzyme activities and soil nutrients

\begin{tabular}{|c|c|}
\hline Variable & Regression equation \\
\hline \multirow{4}{*}{ Microalgal-microbial biomass } & Chlorophyll $a=0.004 \times$ Microbial biomass $\mathrm{C}^{* *}+13.241 \times$ Total salts $^{* *}+11.742 \times \mathrm{APP}^{*}-3.552^{*}\left(R^{2}=0.866, P<0.01\right)$ \\
\hline & Microbial biomass $\mathrm{C}=1.852 \times$ invertase $^{* *}-3823.579 \times \mathrm{APP}^{*}+481.639^{* *}\left(R^{2}=0.576, P<0.01\right)$ \\
\hline & Organic $\mathrm{C}=3.33 \times$ Urease $^{* *}+1.27\left(R^{2}=0.572, P<0.01\right)$ \\
\hline & Total N=0.39 $\times$ Urease $^{* *}+0.20\left(R^{2}=0.580, P<0.01\right)$ \\
\hline \multirow{4}{*}{ Soil nutrients } & Total $\mathrm{P}=0.01 \times$ chlorophyll $a+0.36\left(R^{2}=0.534, P<0.01\right)$ \\
\hline & Available $\mathrm{N}=26.86 \times$ Urease $^{* *}+108.03 \times \mathrm{APP}^{*}+5.45\left(R^{2}=0.625, P<0.01\right)$ \\
\hline & Available $\mathrm{P}=2.42 \times$ Urease $^{* *}-0.001 \times$ Microbial biomass $\mathrm{C}^{* *}+2.84\left(R^{2}=0.589, P<0.01\right)$ \\
\hline & Available $\mathrm{K}=58.183 \times$ Urease $^{* *}+105.047\left(R^{2}=0.412, P<0.01\right)$ \\
\hline
\end{tabular}

APP may result in their negative correlation.

Nitrogen fixation takes place in some heterocystic and non-heterocystous cyanonbacteria genera occurring in well developed BSCs, such as Nostoc, Nodularia, Schizothrix, Scytonema, Tolypothrix, Microcoleus, Lynbya, Oscillatoria and Phormidium. Some bacteria associated with cyanobacteria may contribute to $\mathrm{N}$ inputs in the desert soil. Nitrogen fixation has also been demonstrated in soil lichen with cyanobacteria photobionts, such as Collema sp. and Heppia spp. (Belnap and Lange, 2003). Enzyme activity is dependent on both resource availability and microbial growth (Mager and Thomas, 2011). Nitrogen fixed by cyanobacteria, bacteria and lichen offers an abundant substrate for urease, which increases urease activity. Urease in the soil can transfer organic $\mathrm{N}$ into mineralized $\mathrm{N}$, and produce more mineralized $\mathrm{N}$ (Killham, 1994), thus increasing total and available $\mathrm{N}$ as the BSCs develop.

Urease may be an indirect factor to have an effect on available $\mathrm{P}$ and $\mathrm{K}$. Improvement of total and available $\mathrm{N}$ can promote the growth of cyanobacteria and bacteria. Increase of microalgal biomass is helpful to improve organic C, APP activity and available P. The release of carbonic acid by the algal cells can accelerate the weathering of minerals, hence make improvement of inorganic ions, such as available K (Killham, 1994), inferring that urease has a significant correlation with available $\mathrm{P}$ and $\mathrm{K}$. Greater urease and alkaline phosphatase activities can increase the contents of soil nutrients. Therefore, organic $\mathrm{C}$, total $\mathrm{N}$, available $\mathrm{N}, \mathrm{P}$ and $\mathrm{K}$ were conclusively and significantly correlated with urease and APP in the present research.

When mosses, such as Syntrichia caninervis, established and dominated in BSCs, the number of species and biomass of cyanobacteria, eukaryotic algae and heterotrophic bacteria decline due to the competition with mosses (Zhang et al., 2009), followed by microbial biomass and some of enzyme activities decrease. However, the growth of mosses can also contribute to 
the soil organic carbon. Moreover, seed plants become abundant with the development of BSCs ( $\mathrm{Li}$ et al., 2005). Plant material is also rich in lignin. Soil microbes and abiotic reactions reprocess plant inputs into even more complex (and often insoluble) materials, such as humic compounds that require oxidative enzyme for their degradation (Killham, 1994; Singer and Munns, 2006). Thus, peroxidase enzymes also increase with the development of BSCs.

\subsection{The role of biotic factors of BSCs on accu- mulation of soil salts}

Directly or indirectly microorganisms in the desert soils induce mineral disaggregation, hydration, dissolution and secondary mineral formation. Polysaccharides secreted by cyanobacteria and heterotrophic microorganisms can suppress or enhance rates of chemical weathering (Killham, 1994). Plant roots, fungi and lichen that occupy fractures or encrust a rock produce and release organic acids that promote the decomposition and weathering of minerals, which improve inorganic ions. Therefore, soil nutrients, electronic conductivity or total salts increase with BSCs succession (Banfield et al., 1999).

\subsection{Insight from microbial activities and nutrients in the succession of BSCs}

BSCs are capable of modifying nutrient availability to favor the establishment of biogeochemical cycles (Belnap and Lange, 2003). Crusts organisms show obvious differences with the succession of BSCs (Eldridge and Greene, 1994; Redfield et al., 2002; Yeager et al., 2004). Soil microbial activity plays essential roles in soil nutrient transformation in BSCs, whereas soil microbial biomass contributes to total organic $\mathrm{C}$ in soil and can be an important source of nutrients to plants because of its fast turnover (Glaciela et al., 2010). From the present research, microalgal biomass, microbial biomass, enzyme activities were the highest in lichen or moss crusts, which showed important effects on the contents of nutrients in the successional stages of BSCs. Late successional crusts (such as lichen crusts or moss crusts) can contribute more nutrients inputs to the soil and provide a favorable environment for survival and growth of higher plant (Harper and Belnap, 2001; Li et al., 2005). The results help us to understand developmental mechanism of BSCs based on microbial activities and physical-chemical properties.

\section{Conclusion}

Microbial biomass and most of hydrolytic enzyme activities increased with the development of BSCs, and the chlorophyll $a$ and microbial biomass $\mathrm{C}$ promoted each other. They reached the highest in lichen crusts or moss crusts. The growth of cyanobacteria and microorganisms could accumulate organic matter and $\mathrm{N}$ by photosynthesis and $\mathrm{N}$ fixation, which offered substrates for enzyme activities and improved enzyme activities, such as invertase, ALP and urease activities. Improvement in enzyme activities could increase soil fertility and ultimately promoted the growth of microalgae and other microorganisms, which further accelerated the succession of BSCs.

\section{Acknowledgements}

This work was financially supported by the National Natural Science Foundation of China (41071041, U1203301) and the West Light Foundation of Chinese Academy of Sciences (RCPY201101). We would like to thank two reviewers for their constructive comments and suggestions on revising the manuscript.

\section{References}

Ajwa H A, Dell C J, Rice C W. 1999. Changes in enzyme activities and microbial biomass of tallgrass prairie soil as related to burning and nitrogen fertilization. Soil Biology \& Biochemistry, 31: 769-777.

Allison S D, Jastrow J D. 2006. Activities of extracellular enzymes in physically isolated fractions of restored grassland soils. Soil Biology \& Biochemistry, 38: 3245-3256.

Baldrian P, Merhautova V, Petrankova M T, et al. 2010. Distribution of microbial biomass and activity of extracellular enzymes in a hardwood forest soil reflect soil moisture content. Applied Soil Ecology, 46: 177-182.

Banfield J F, Barker W W, Welch S A, et al. 1999. Biological impact on mineral dissolution: Application of the lichen model to understanding mineral weathering in the rhizosphere. Proceedings of the National Academy of Sciences, USA, 96: 3404-3411.

Belnap J, Gillette D A. 1997. Disturbance of biological soil crusts: Impacts on potential wind erodibility of sandy desert soils in southeastern Utah. Land Degradation and Development, 8: 355-362.

Belnap J. 2002. Nitrogen fixation in biological soil crusts from southeast Utah, USA. Biology and Fertility of Soil, 35: 128-135.

Belnap J, Phillips S L. 2002. Biological soil crusts: Effects of global change on ecosystem roles and restoration. Ecological Society of America Annual Meeting Abstracts, 87: 9.

Belnap J, Lange O L. 2003. Biological Soil Crusts: Structure, Function, 
and Management. Berlin: Springer, 3-30.

Brotoff W N. 2002. Cryptobiotic crusts of a seasonally inundated Dune-Pan system at Edwards Air Force Base, Western Mojave Desert, California. Journal of Arid Environments, 51: 339-361.

Catford J A, Walsh C J, Beardall J. 2007. Catchment urbanization increases benthic microalgal biomass in streams under controller light conditions. Aquatic Sciences, 69: 511-522.

Chamizo S, Canton Y, Lazaro R, et al. 2012a. Crust composition and disturbance drive infiltration through biological soil crusts in semiarid ecosystems. Ecosystems, 15: 148-161.

Chamizo S, Canton Y, Miralles I, et al. 2012b. Biological soil crust development affects physicochemical characteristics of soil surface in semiarid ecosystems. Soil Biology \& Biochemistry, 49: 96-105.

Chen L Z, Xie Z M, Hu C X, et al. 2006. Man-made desert algal crusts as affected by environmental factors in Inner Mongolia, China. Journal of Arid Environments, 67: 521-527.

Chen Y N, Wang Q, Li W H, et al. 2007. Microbiotic crusts and their interrelations with environmental factors in the Gurbantunggut Desert, Western China. Environmental Geology, 52: 691-700.

Dick R P. 1994. Soil enzyme activities as indicators of soil quality. In: Doran J W, Coleman D C, Bezdicek D F, et al. Defining Soil Quality for a Sustainable Environment. Madison: American Society of Agronomy, 107-124.

Eldridge D J, Greene R S B. 1994. Microbiotic soil crusts-a review of their roles in soil and ecological processes in the rangelands of Australia. Australian Journal of Soil Research, 32: 389-415.

Evans R D, Johansen J R. 1999. Microbiotic crusts and ecosystem processes. Critical Reviews in Plant Sciences, 18: 183-225.

Evans R, Lange O. 2003. Biological soil crusts and ecosystem nitrogen and carbon dynamics. In: Belnap J, Lange O L. Biological Soil Crusts: Structure, Function, and Management. New York: Springer, 263-279.

Glaciela K, Odair A, Mariangela H. 2010. Three decades of soil microbial biomass studies in Brazilian ecosystems: Lessons learned about soil quality and indications for improving sustainability. Soil Biology \& Biochemistry, 42: 1-13.

Grote E E, Belnap J, Housman D C, et al. 2010. Carbon exchange in biological soil crust communities under differential temperatures and soil water contents: implications for global change. Global Change Biology, 16: 2763-2774.

Guo Y R, Zhao H L, Zuo X A, et al. 2008. Biological soil crust development and its topsoil properties in the process of dune stabilization, Inner Mongolia, China. Environmental Geology, 54: 653-662.

Harel Y, Ohad I, Kaplan A. 2004. Activation of photosynthesis and resistance to photoinhibition in cyanobacteria within biological desert crust. Plant Physiology, 136: 3070-3079.

Harper K T, Belnap J. 2001. The influence of biological soil crusts on mineral uptake by associated vascular plants. Journal of Arid Environments, 47: 347-357.

Hawkes C V, Flechtner V R. 2002. Biological soil crusts in a xeric Florida shrubland: composition, abundance, and spatial heterogeneity of crusts with different disturbance histories. Microbial Ecology, 43: 1-12.
Hernandez D L, Hobbie S E. 2010. The effects of substrate composition, quantity, and diversity on microbial activity. Plant and Soil, 335: 397-411.

Housman D C, Powers H H, Collins A D, et al. 2006. Carbon and nitrogen fixation differ between successional stages of biological soil crusts in the Colorado Plateau and Chihuahuan Desert. Journal of Arid Environments, 66: 620-634.

Kandeler E, Mosier A R, Morgan J A, et al. 2006. Response of soil microbial biomass and enzyme activities to the transient elevation of carbon dioxide in a semi-arid grassland. Soil Biology \& Biochemistry, 38: 2448-2460.

Katsalirou E, Deng S P, Nofziger D L, et al. 2010. Long-term management effects on organic $\mathrm{C}$ and $\mathrm{N}$ pools and activities of C-transforming enzymes in prairie soils. European Journal of Soil Biology, 46: 335-341.

Killham K. 1994. Soil Ecology. Cambrige: Cambridge University Press, 40-61.

Lan S B, Wu L, Zhang D L, et al. 2012a. Successional stages of biological soil crusts and their microstructure variability in Shapotou region (China). Environmental Earth Sciences, 65: 77-88.

Lan S B, Wu L, Zhang D L, et al. 2012b. Composition of photosynthetic organisms and diurnal changes of photosynthetic efficiency in algae and moss crusts. Plant and Soil, 351: 325-336.

Li X R, Jia X H, Long L Q, et al. 2005. Effects of biological soil crusts on seed bank, germination and establishment of two annual plant species in the Tengger Desert (N China). Plant and Soil, 277: 375-385.

Mager D M, Thomas A D. 2011. Extracellular polysaccharides from cyanobacterial soil crusts: a review of their role in dryland soil processes. Journal of Arid Environments, 75: 91-97.

Miralles I, Domingo F, Canton Y, et al. 2012. Hydrolase enzyme activities in a successional gradient of biological soil crusts in arid and semi-arid zones. Soil Biology \& Biochemistry, 53: 124-132.

Rao B Q, Liu Y D, Wang W B, et al. 2009. Influence of dew on biomass and photosystem II activity of cyanobacterial crusts in the Hopq Desert, northwest China. Soil Biology \& Biochemistry 41: 2387-2393.

Redfield E, Barns S M, Belnap J, et al. 2002. Comparative diversity and composition of cyanobacteria in three predominant soil crusts of the Colorado Plateau. FEMS Microbiology Ecology, 40: 55-63.

Rose C, Axler R P. 1998. Uses of alkaline phosphatase activity in evaluating phytoplankton community phosphorus deficiency. Hydrobiologia, 361: 145-156.

Singer M J, Munns D N. 2006. Soils-An Introduction. Ohio: Pearson Prentic Hall, 158-189.

Su Y G, Zhao X, Li A X, et al. 2011. Nitrogen fixation in biological soil crusts from the Tengger desert, northern China. European Journal of Soil Biology, 47: 182-187.

Su Y G, Wu L, Zhou Z B, et al. 2013. Carbon flux in deserts deponds on soil cover type: A case study in the Gurbantunggut Desert, North China. Soil Biology \& Biochemistry, 58: 332-340.

Vance E D, Brookes P C, Jenkinson D S. 1987. An extraction method for measuring soil microbial biomass C. Soil Biology \& Biochemistry, 19: 703-707. 
Wu N, Zhang Y M, Downing A. 2009. Comparative study of nitrogenase activity in different types of biological soil crusts in the Gurbantunggut Desert, Northwestern China. Journal of Arid Environments, 73: 828-833.

Yeager C M, Kornoshy J L, Housman D C, et al. 2004. Diazotrophic community structure and function in two stages of biological soil crusts from the Colorado Plateau and Chihuahuan Desert. Applied and Environmental Microbiology, 70: 973-983.

Yu J, Kidron G J, Pen-Mouratov S, et al. 2012. Do development stages of biological soil crusts determine activity and functional diversity in a sand-dune ecosystem? Soil Biology \& Biochemistry, 51: 66-72.

Zeng X Q, Hou Y J, Yang Z C, et al. 2013. Chlorophyll fluorescence of desiccation-tolerant cyanobacterial crusts of sub-tropical inselberg rocks in southern China: 2. Rehydration at different light intensities and temperatures. Nova Hedwigia, 96: 511-524.

Zhang B C, Zhang Y M, Zhao J C, et al. 2009. Microalgal species variation at different successional stages in biological soil crusts of the Gurbantunggut Desert, Northwestern China. Biology and Fertility of Soils, 45: 539-547.

Zhang B C, Zhang Y M, Downing A, et al. 2011. Distribution and com- position of cyanobacteria and microalgae associated with biological soil crusts in the Gurbantunggut Desert, China. Arid Land Research and Management, 25: 275-293.

Zhang B C, Zhang Y M, Su Y G, et al. 2013. Responses of microalgal-microbial biomass and enzyme activities of biological soil crusts to moisture and inoculated Microcoleus vaginatus gradients. Arid Land Research and Management, 27: 216-230.

Zhang Y M. 2005. The microstructure and formation of biological soil crusts in their early developmental stage. Chinese Science Bulletin, 50: 117-121.

Zhang Y M, Chen J, Wang L, et al. 2007. The spatial distribution patterns of biological soil crusts in the Gurbantunggut Desert, Northern Xinjiang, China. Journal of Arid Environments, 68: 599-610.

Zhang Y M, Wu N, Zhang B C, et al. 2010. Species composition, distribution patterns and ecological functions of biological soil crusts in the Gurbantunggut Desert. Journal of Arid Land, 2: 180-189.

Zhou X B, Zhang Y M, Downing A. 2012. Non-linear response of microbial activity across a gradient of nitrogen addition to a soil from the Gurbantunggut Desert, northwestern China. Soil Biology \& Biochemistry, 47: 67-77. 